بررسى رابطه فيلوزنتيك تعدادى از گونهاى وحشى بادام ايران بـا بهرهگيرى از تـوالىهاى ناحيه ITS

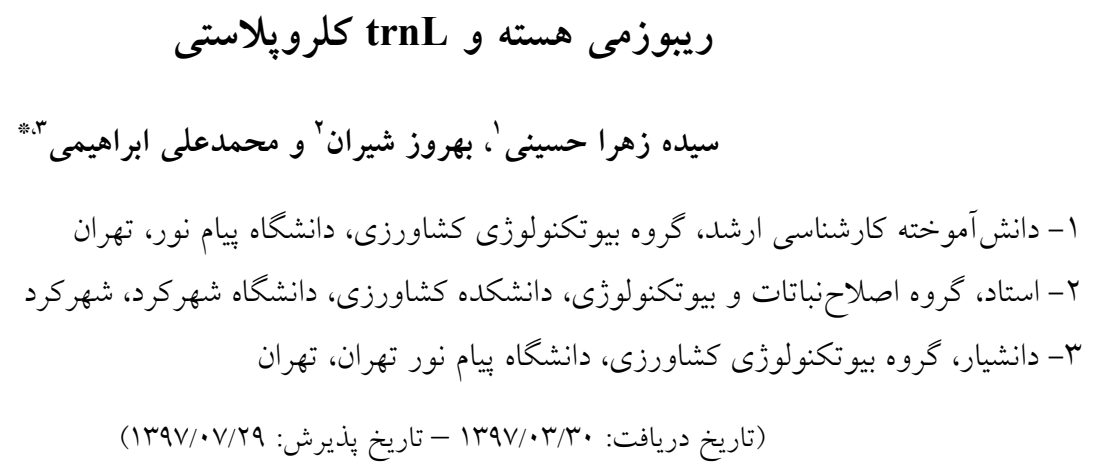

رابطه فيلوزنتيك بين rا كونه وحشى Prunus، يك رقم زراعى بادام و يكى رقم هلو، با استفاده از توالىهاى ناحيه

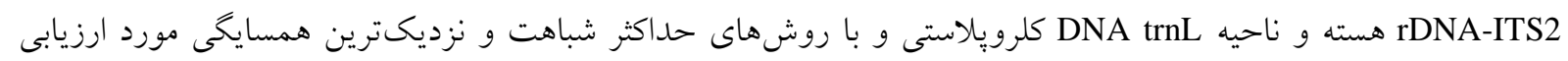

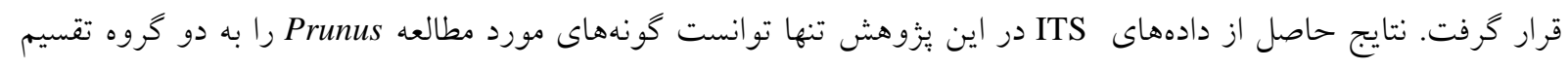

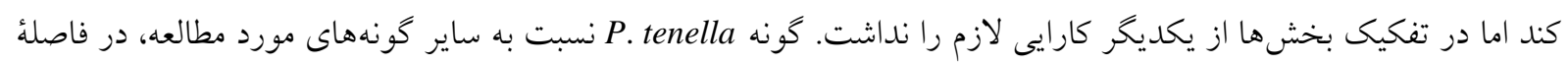

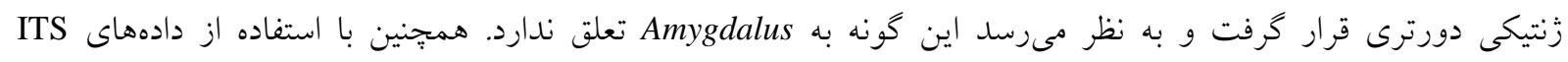

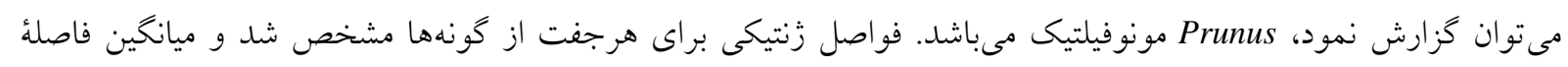

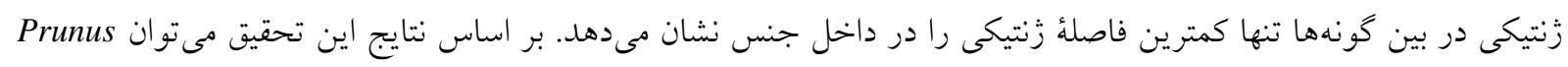

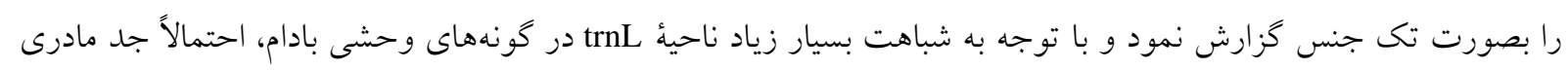

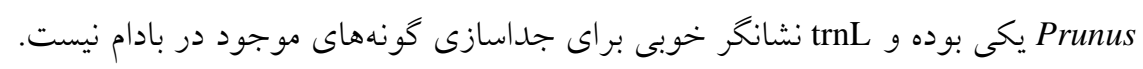
واز كان كليدى: فيلوزنى، Prunus species ، ITS1-5.8S rDNA-ITS2، كلرويلاستى 


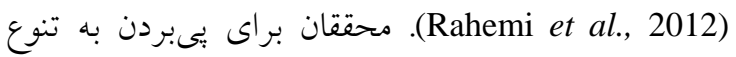

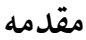
زنتيكى ميان بادامها از روشهاى مختلفى به ويزه روش DNA استفاده كردهاند. نشانكر ITS AFLP ITS1-5.8s rDNA- ريبوزومى هسته مىباشد كه ناحية

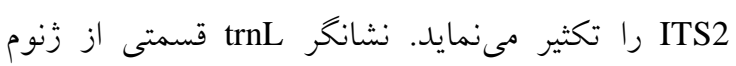
بزرى كلرويلاست است كه ناحية trnT را تكثير مى كند و

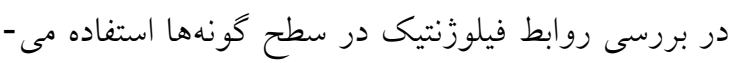

شود (Potter et al., 1999; Sorkheh et al., 2007). برخى محققين (Taberlet et al., 1999) بيان نمودند كه

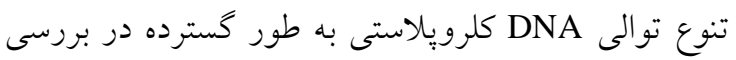

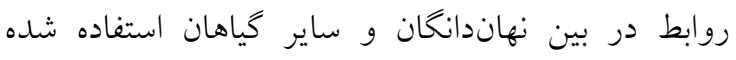
است، ولى به علت تكامل كم cpDNA، در سطح درون كونهاى به خوبى قابل استفاده نمىباشد. يزوهشهاى زيادى در زمينه بررسى رابطه فيلوزنى در خانواده Browicz, ) Browicz صورت گرفته است. Rosaceae 1969) و و همكاران (Khanuja et al., 1999) جنس Amygdalus (ايرانى) را به دو زيرجنس Ddecandra Amygdalus Spartioides Amygdalus شامل دو بخش Amygdalus بود. بخش Amygdalus شامل r آ كونه مىباشد كه در دو

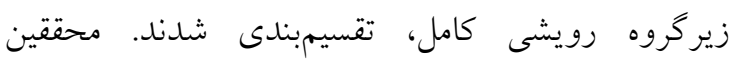
بيان (Khanuja et al., 1999; Vadafar et al., 2010) نمودند كه تاكسنومى Amygdalus مانند ساير جنس هاى خانوادة Rosaceae بسيار مشكل است. علت اين امر ميزان

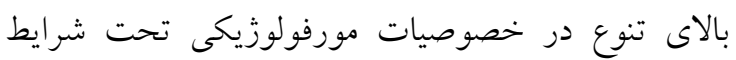

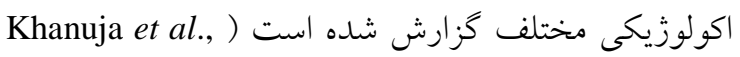
1999). اين جنس تنوع زئن زيادى در سطح كونه، هيبريداسيون بالا در بين كونهها و هومويلاستى بالايى تحت شرايط اكولوزيكى نشان مىدهد. بنابراين طبقه

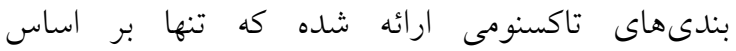
خصوصيات مورفولوزيكى صورت گرفتهاند، اطلاعات كافى براى جداسازى گونها و تعيين حدود واضح بين كونهاى اين جنس ارائه نكردهاند. اين امر ضرورت فيكت بررسى هاى مولكولى، بيوشيميايى و ميكرومورفولوزيكى لتحني بادام با نام علمى Prunus dulcis متعلق به خانواده Rosaceae

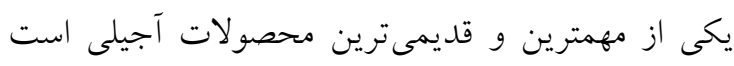

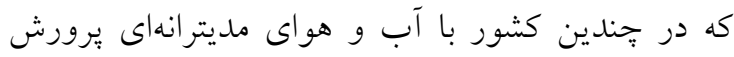

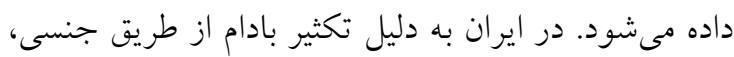

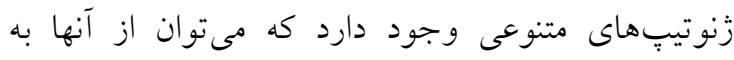

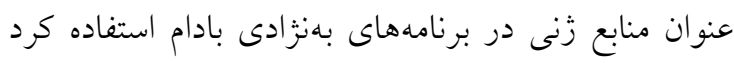

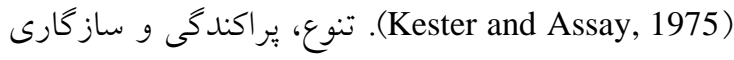

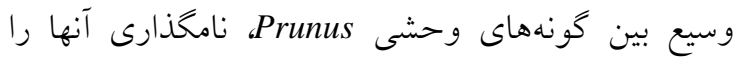
مشكل نموده است (Martınez-Gomez et al., 2003). اين موضوع به يزوهشهاى متعددى در اين زمينه نياز

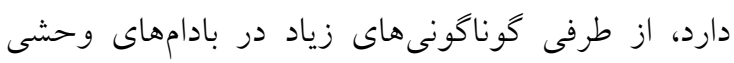

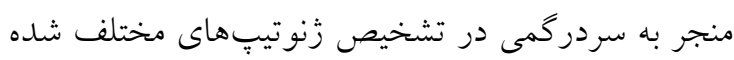

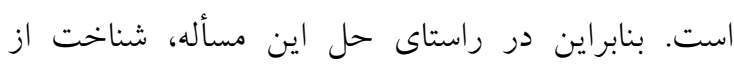

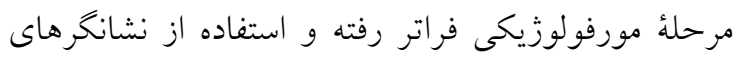

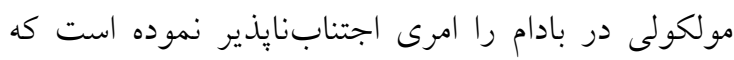

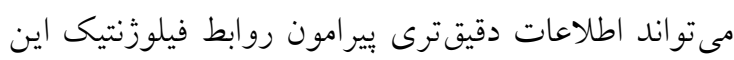

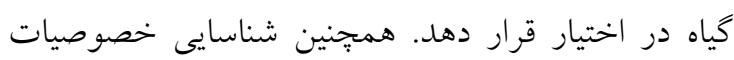
زنتيكى بادام وحشى بدليل وجود زنهاى مقاوم به شرايط

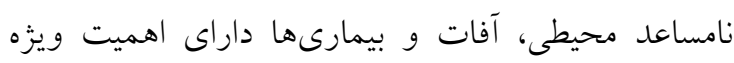
است (Rahemi et al., 2012). بنابراين از تنوع بالاى

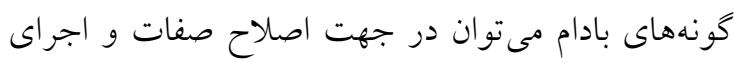
هرجهه بهتر برنامههاى اصلاحى سود برد.

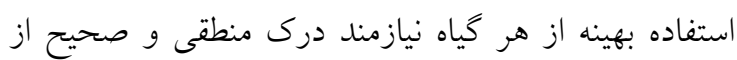
سطح تنوع زنتيكى آن محصول در طبيعت و همجنين

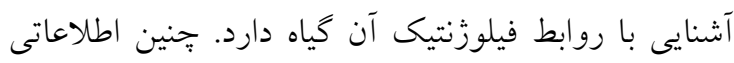
منجر به توجه بيشتر بلنزادكران گياهى و ديخر

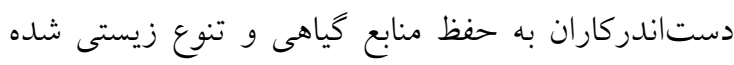
و از فرسايش زنتيكى گياهان ارزشمند جلو گيرى مى كند.

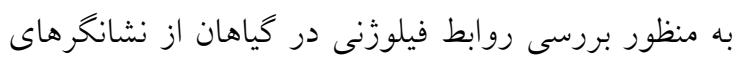

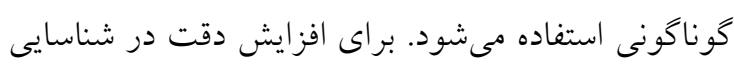

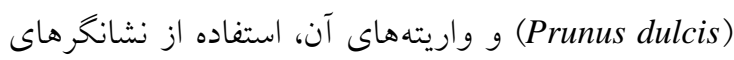
زنتيكى و روشهاى مولكولى، ضرورى به نظر مىرسد 
استخراج DNA انتخاب گرديد. بدين منظور برى كياهان

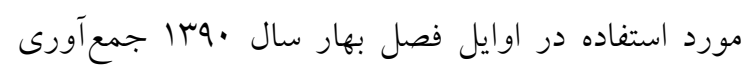
كرديد و از روش تغييريافته (Khanuja et al., 1999) شد. فهرست آغازگرهايى كه در اين تحقيق براى تكثير

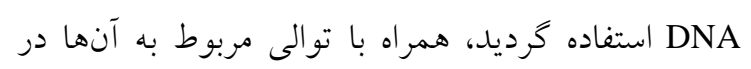

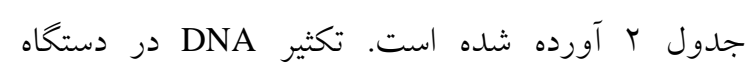
ترموسايكلر (إيندرف) مدل Mastercycler Gradient براى آغازكر ITS و trnL در حجم واكنش ل0 ميكروليتر

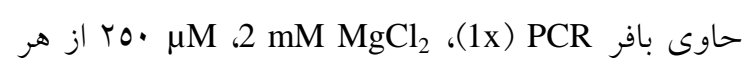

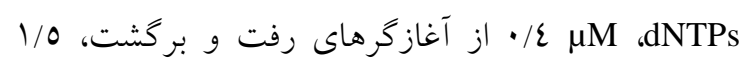

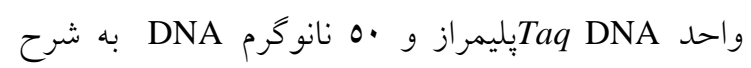
ذكر شده و بر اساس روش CTAB تغيير يافته ( Murray Khanuja et al., ) PVP همراه با تعنه (and Thamson, 1980

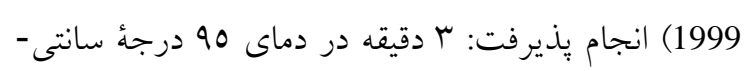

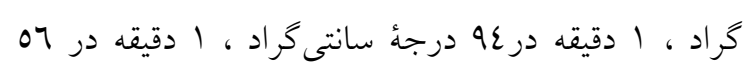

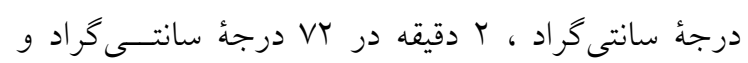

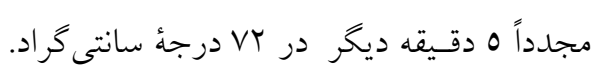

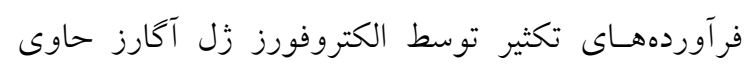

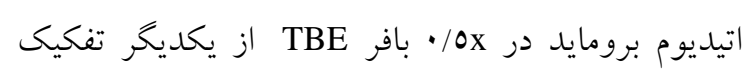

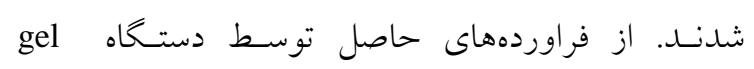
documentation

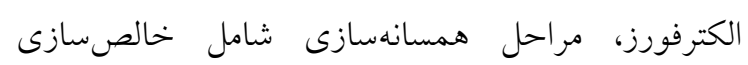
فراوردههاى PCR با استفاده از كيت ( GeneJet PCR purification kit (Fermentas

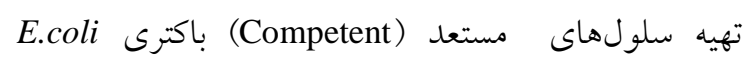
(سويه DH5A) از روش تغييريافته كلريدكلسيم برانو

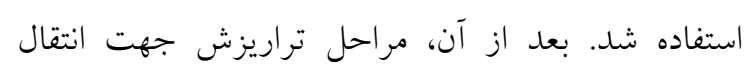

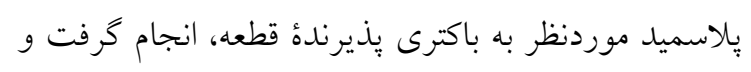

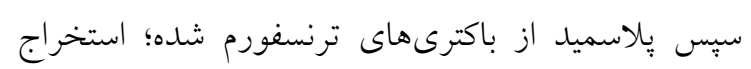
كرديد.

2- Polyvinylpyrrolidone
را براى انجام طبقهبندى تاكسونوميكى واضح و بررسى

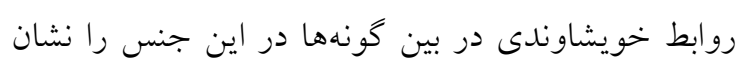
مى دهد. در كزارش Lee and Wen, 2001) Lee and Wen با دهر

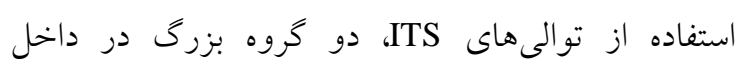
Prunus - Amygdaloideae و Oemleria ، Exochorda -r Maddenia, همجنين آنها با استفاده از اين توالىها دو .Pirensepia

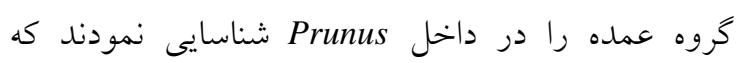

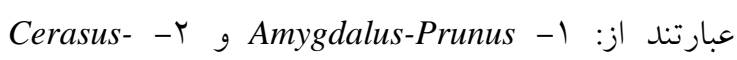
همجينين اين محققان با توجه به توالىهاى ITS، وجود روابط نزديك بين زيرجنس هاى إنين

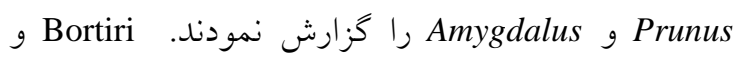
همكاران (Bortiri et al., 2006) در يُزوهش خود تلاش نمودند با استفاده از دو نشانكر ITS و trnL-F به بازسازى

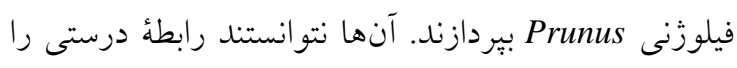
در بين كونههاى مربوط به زيرجنس Amygdalus بانس

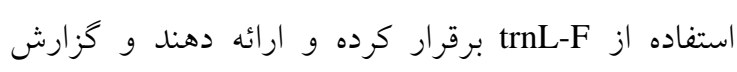
نمودند كه Amygdalus بِارافيلتيك' مى باشد. به عبارت

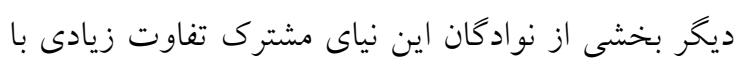

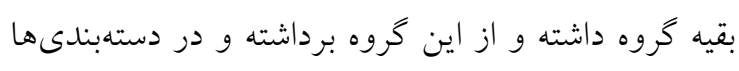

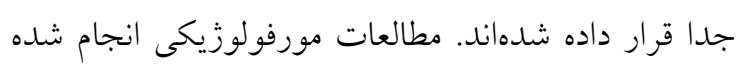

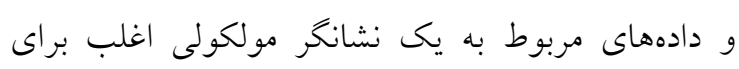

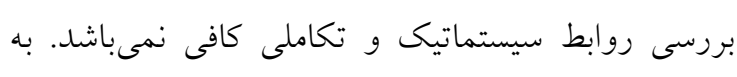

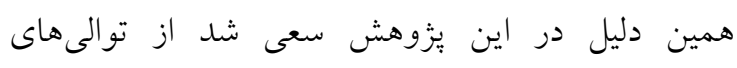

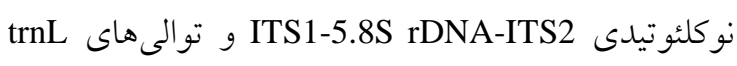

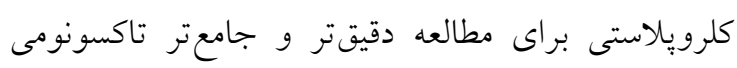
Prunus dulcis مواد و روشها

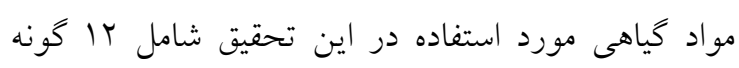
وحشى Prunus، يك رقم زراعى بادام و يك رقم هلو

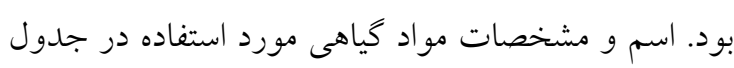

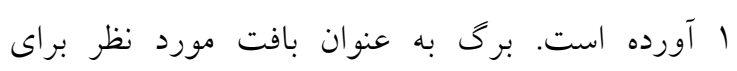

1- Paraphyletic 
جدول 1- مشخصات مواد گياهى مورد استفاده در اين تحقيق

Table 1. Profile of plant material used in this study

\begin{tabular}{|c|c|c|c|c|c|c|}
\hline رديف & $\begin{array}{c}\text { نام گونه } \\
\text { Species name }\end{array}$ & منشأ & Origin & وضعيت ساز كارى & $\begin{array}{c}\text { Compatibility } \\
\text { status }\end{array}$ & $\begin{array}{l}\text { يسوند شماره } \\
\text { Suffix } \\
\end{array}$ \\
\hline 1 & P. arabica & ايران & Iran & خودساز گار & Self-Compatible & KC603732 \\
\hline 2 & P. bucharica & افغانستان & Afghanistan & خودساز گار & Self-Compatible & KC603733 \\
\hline 3 & P. communis & 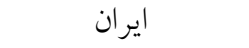 & Iran & نامشخص & Undetermined & КC603734 \\
\hline 4 & P. dulcis & ايران & Iran & نامشخص & Undetermined & KC603735 \\
\hline 5 & P. eleagnifolia & 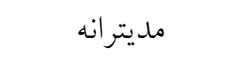 & Mediterranean & خودساز گار & Self-Compatible & КС603736 \\
\hline 6 & P. glauca & 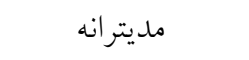 & Mediterranean & خودساز گار & Self-Compatible & KC603737 \\
\hline 7 & P. hausknechtii & 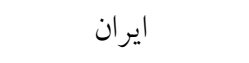 & Iran & خودساز گار & Self-Compatible & КС603738 \\
\hline 8 & P. kuramica & افغانستان و يِاكستان & Afghanistan and Pakistan & خودساز گار & Self-Compatible & КС603739 \\
\hline 9 & P. lycioides & 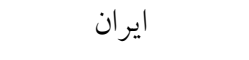 & Iran & نامشخص & Undetermined & КС603740 \\
\hline 10 & P. orientalis & ايران & Iran & نامشخص & Undetermined & КС603741 \\
\hline 11 & P. persica & 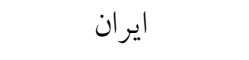 & Iran & خودساز كار & Self-Compatible & KC603742 \\
\hline 12 & P. scoparia & 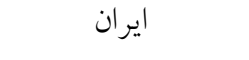 & Iran & ن امشتص & Undetermined & КC603743 \\
\hline 13 & P. tenella & 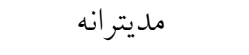 & Mediterranean & نامشخص & Undetermined & КC603744 \\
\hline 14 & P. webbii & مايتر انه & Mediterranean & خودساز گار & Self-Compatible & KC603745 \\
\hline
\end{tabular}

جدول r - ليست آغاز گرهاى مورد استفاده در اين تحقيق

Table 2. The primers that used in this study

\begin{tabular}{|c|c|c|}
\hline $\begin{array}{c}\text { نام آغازگر } \\
\text { (Primer name) }\end{array}$ & 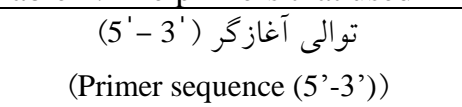 & $\begin{array}{c}\text { منبع } \\
\text { (Reference) }\end{array}$ \\
\hline $\begin{array}{l}\operatorname{trnL-R} \\
\text { trnL-F } \\
\text { ITS1 } \\
\text { ITS4 } \\
\end{array}$ & $\begin{array}{c}\text { GGGGATAGAGGGACTTGAAC } \\
\text { CGAAATCGGTAGACGCTACG } \\
\text { TCCGTAGGTGAACCTGCGG } \\
\text { TCCTCCGCTTATTGATATGC } \\
\end{array}$ & $\begin{array}{c}\text { Taberlet } \text { et al. } 1991 \\
\text { Taberlet } \text { et al. } 1991 \\
\text { Baldwin } 1993 \\
\text { Baldwin } 1993 \\
\end{array}$ \\
\hline
\end{tabular}

يس از توالىيابى دو طرفه، توالى مربوط به پِاسميد، توسط برنامه EditSeq حذف شد. با توجه به يكسان بودن

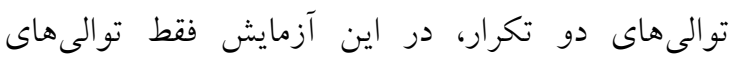

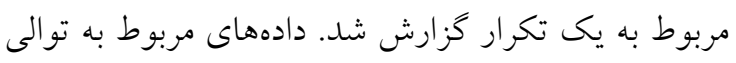
ناحئ ITS1-5.8s rDNA-ITS2 و ناحئ كلروبِاستى rا گونه وحشى Prunus، يك رقم زراعى بادام و يك رقم هلو توسط برنامه CLUSTAL X هم رديف شدند. ميزان تناسب همرديفىها با آناليز فيلوزنيك، به كمك روش آناليز نقشهيابى حداكثر درستنمايى' TREE-PUZZLE-5.2 و با بكاركيرى نرم افزار (LMA)

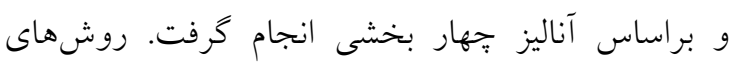

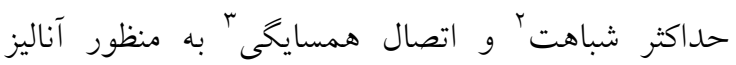

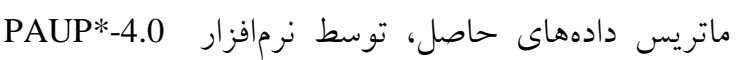
beta مورد بررسى قرار گرفت. براى افزايش اطمينان از

1- Likelihood Mapping Analysis (LMA)

2- Maximum-parsimony

3- Neighbor joining
از كيت (cat\#:BSA12M1)) BioReady rTaq ساخت شركت BioFlux براى Colony PCR و Taq ساخت شركت PCR براى Priagen بوط و استفاده شد. روش Colony PCR جهت تأييد كلون- ITS هاى نوتركيب مورد استفاده قرار كرفت. در اين يزوهش جهت استخراج يِاسميد از كلونىهاى نوتركيب مثبت

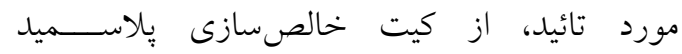
GeneJET ${ }^{\mathrm{TM}}$ Plasmid Miniprep Kit (\#K0503) شد. غلظت هر يك از بِاسميدهاى نوتركيب مربوط به توالىهاى ITS و ITnL با استفاده از دستخاه بيوفتومتر

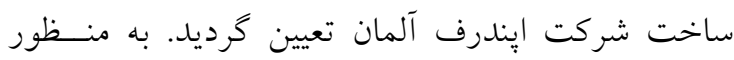
صحت انجام توالىيابى، از هر نمونه دو كلون انتخاب و

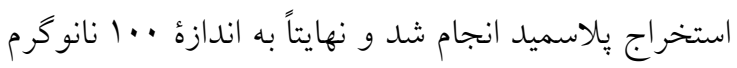
از هر بِلاسميد جهت توالىيابى به شركت Macrogene كره جنوبى ارسال شد. 
بنابراين روش حداكثر درستنمايى تعميم شمارش

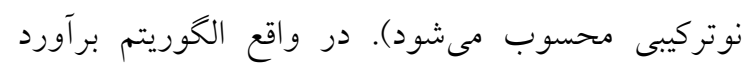

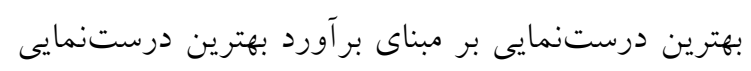
LOD تنظيم شده است.

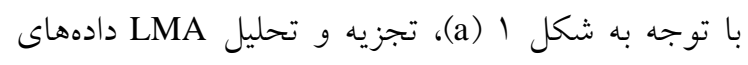

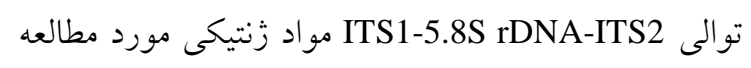
نشان داد كه 71/9 درصد از كل دادههاى مورد مطالعه

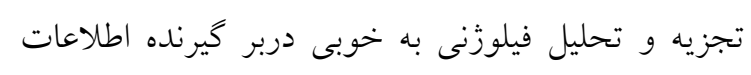

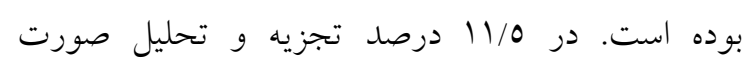

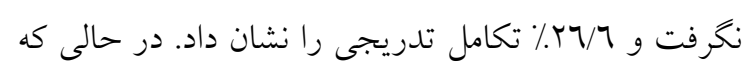

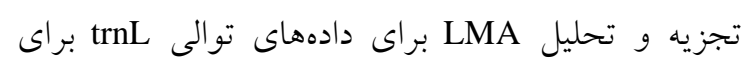

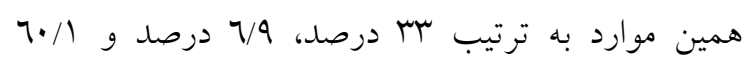
درصد بود (شكل ا b). بر اساس اطلاعات اين آناليز،

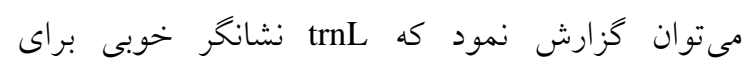
شناسايى روابط فيلوزنى بادام نمى باشد.

فيلوزنى بادام با استفاده از دادههاى ناحيئ rDNA-ITS2

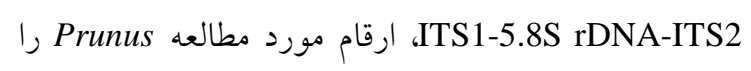

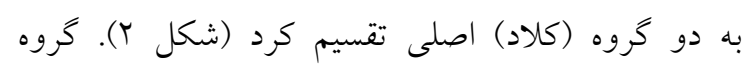

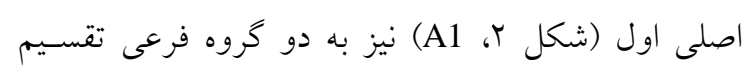

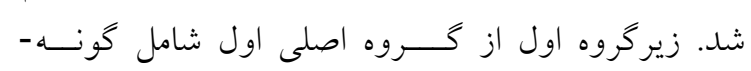
هاى: P. haussknechtii ، P. elaeagnifolia P. tenella ، P. glauca ، P. bucharica ، P.communis ك. كونها، P. P. persica , P. haussknechtii Taberlet et al., 1991; ) اختصاصى ايران مى باشنداي (Khatamsaz, 1992; Potter et al., 1999

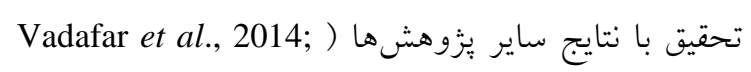
(Yazbek and Oh, 2013

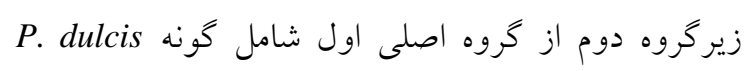

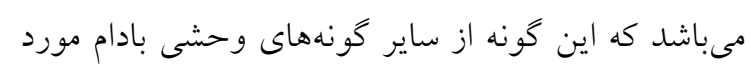

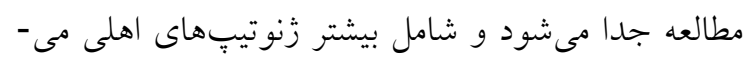

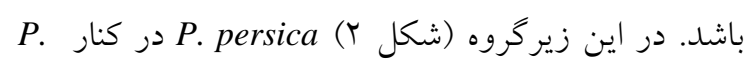

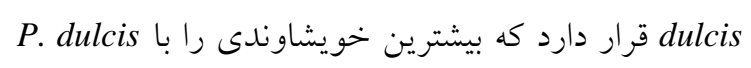

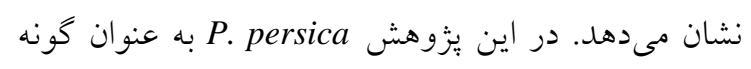
خواهرى P. dulcis معرفى شد.
نتايج حاصل، يكبار ديخر نيز دادهها با استفاده از نرمافزار نسخه V و و روش NJ مورد بررسى قرار كرفتند.

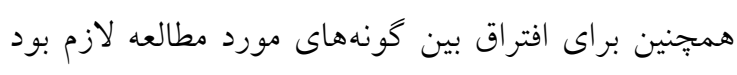

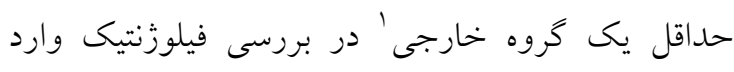

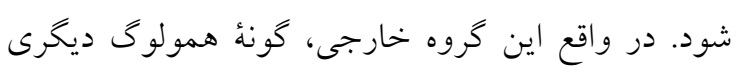
است كه وابستكى كمترى به هريك از كونههاى مورد

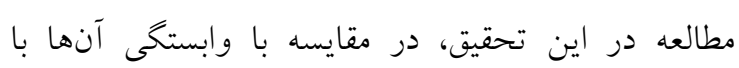

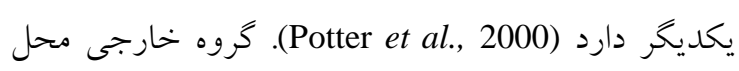
صحيح ريشٔ درخت را در مسير تكاملى، مشخص مى كند.

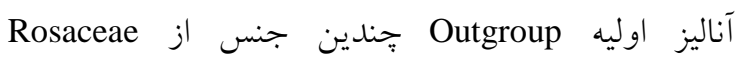
نتوانست Prunus را به خوبى جدا كند؛ لذا در اين مطالعه،

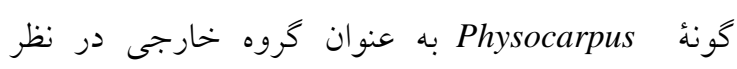
كرفته شد (Potter et al., 2000).

نتايج و بحث در توالىهاى نوكلئوتيدى كه با استفاده از نرمافزار

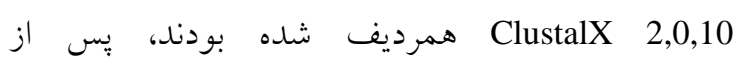

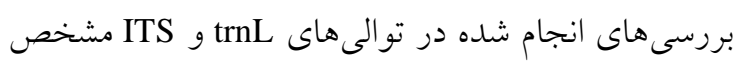

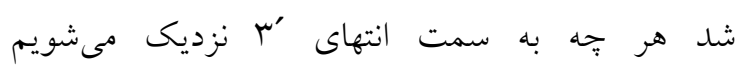
جابهجايى هاى بيشترى رخ داده و در توالى هاى trnL، اين

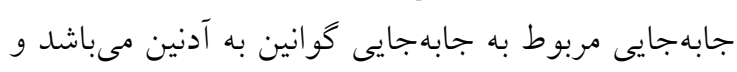

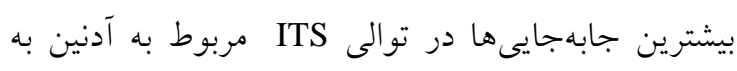

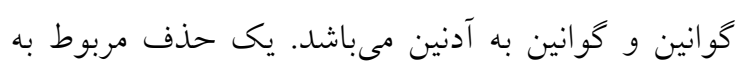

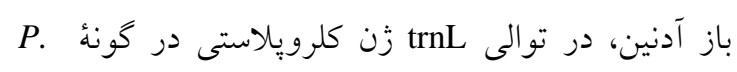
lycioides

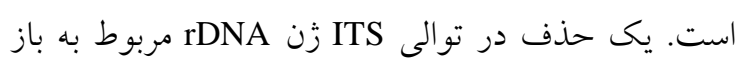

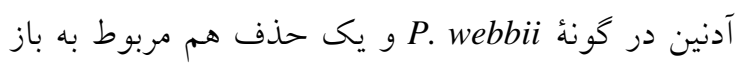
كو انين در كونه P. tenella

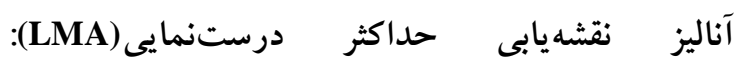
درستنمايى به معناى محاسبه احتمال وجود يكى نقشه

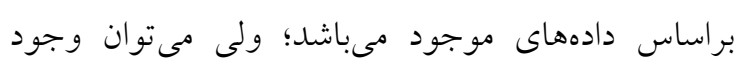
بهترين نقشه را با حداكثر درستنمايى LMA تعيين نمود.

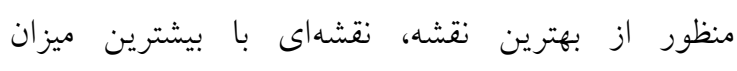

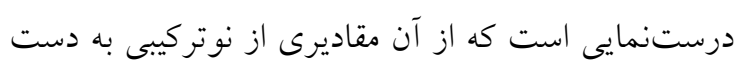

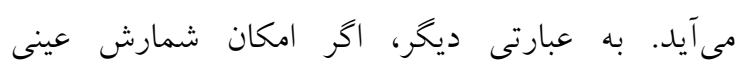

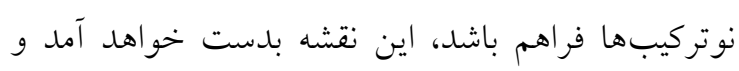

1- Outgroup 


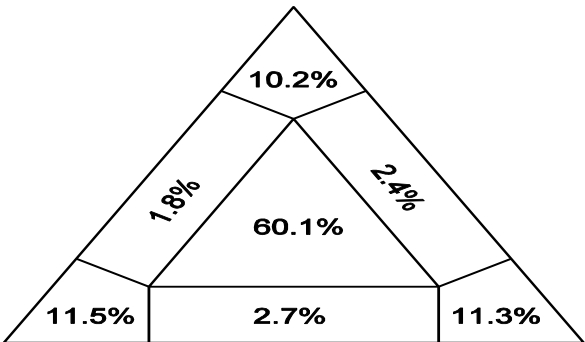

(a)

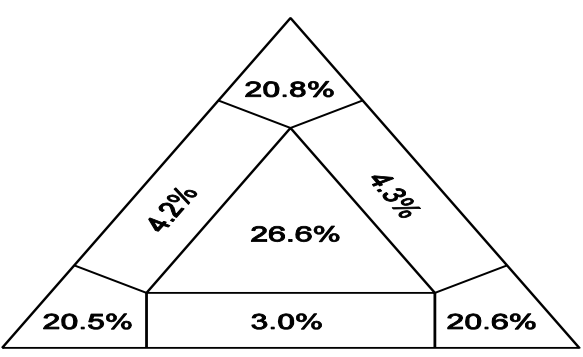

(b)

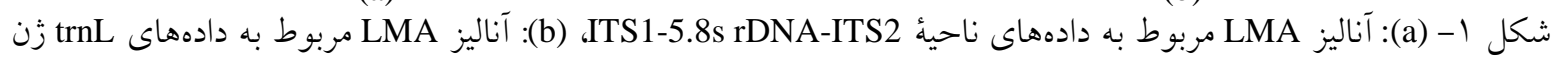
كلرو يالاستى

Figure 1. (a): LMA analysis related to ITS1-5.8s rDNA-ITS2 region data, (b): LMA analysis related to trnL data of chloroplastic gene.

كونههاى P. scoparia

قرار دارند و Socias i Company, ) Socias i Company

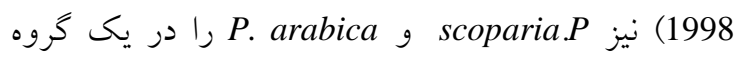
قرار داد. Vadafar و همكاران (Vadafar et al., 2014) نيز با استفاده از خصوصيات تريكوم مورفولوزيكى ميوه بر روى كونههـاى جنس Amygdalus اين دو كونه را در يك كروه قرار دادند و بيان نمودند كـه يكى از خصوصيات بارز اين گروه وجود شاخههاى كوتاه' مى باشد. با توجه به شكل ؟ا، P. persica و P. dulcis در يك بك

$$
\text { كروه و نزديك به هم قرار كرفتند. }
$$

Bortiri خود بيان داشتند كه P. persica از نظر زنتيكى شباهتهاى بسيار زيادى به P. denella dارد. همجنين P. dulcis

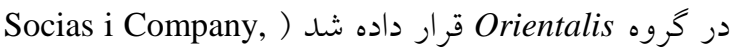
1998). از آنجايى كه در دندروگرام حاصل از توالى ITS اين ثزوهش ، اين گونه نسبت به ساير كونهها در فاصله زنتيكى دورترى نسبت به P. dulcis قرار كرفته است، شايد دليل آن اين است كه اين كونه متعلق به بخش chameamygdalus است كه به سختى با گونههاى زراعى تلاقى مىيابند (Sorkheh et al., 2007) (.زارش شده است كه بايد كونه Yazbek (را از گروه P. Amygdalus tenella and Oh, 2013 (ين مطلب نيز نتايج اين بزوهش را تاييد

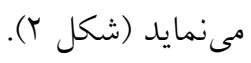

1- Brachyblast
Pملُ گونهاى موجود در گروه اصلى اول (به جز Socias (enella (i Company, 1998 در سرى lcosandrae و در گروه Amygdalus

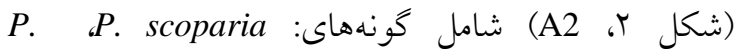
P. P. arabicantalis dycioides در بين اين كونهها P. lycioides انحصارى ايران است Taberlet et al., 1991; Khatamsaz, 1992; Potter et ) Socias Company, (al., 1999 (مبر اساس گزارش قبلى (a) 1998) نيز همه اين گونهها را در يك گروه (Orientalis)

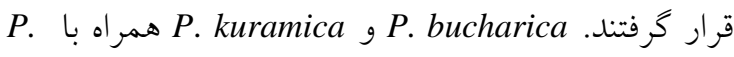
dulcis

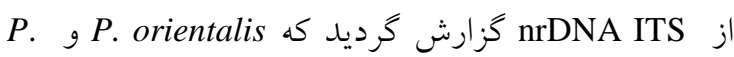
Pcoparia

.(Vadafar et al., 2014)

سرخه و همكاران (Sorkheh et al., 2007) روابط خويشاوندى گونههاى وحشى جنس Prunus را مورد P. bucharica مطالعه قرار داند و گزارش نمودند كه گونهي و P. kuramica از كونهاى خويشاوند نزديك بادامهاى زراعى مىباشند. همجنين اين محققان P. communis را به عنوان جد (نياى) بادامهاى زراعى معرفى نمودند. گونهُ كه در زيرگروه اول از گروه اصلى اول قرار دارد، معمولاً به عنوان يكى از اجداد بادامهاى زراعى ريى در نظر كرفته مىشود. درجه شباهت بين P.communis با P. dulcis 


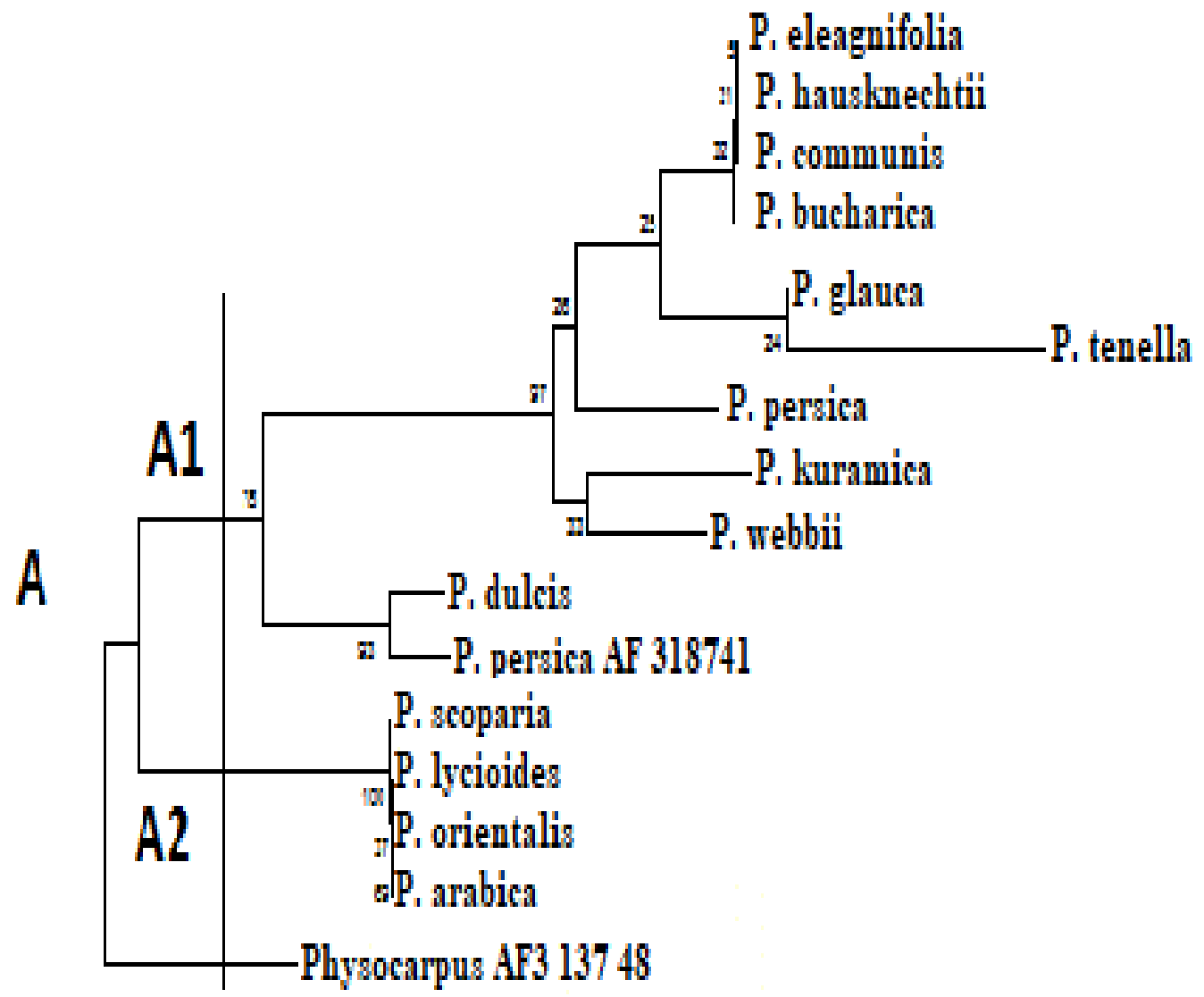

ITS1-5.8s rDNA-ITS2 شكل r- كروهبندى گونههاى وحشى بادام با استفاده از دادههاى ناحية Figure 2. Classification of wild almond, using data from ITS1-5.8s rDNA-ITS2 region

دادههاى ناحيئ ITS ديده مىشود، نسبت به ساير كونهها در فاصلة زْنيكى دورترى نسبت به P. dulcis قرار كرفته

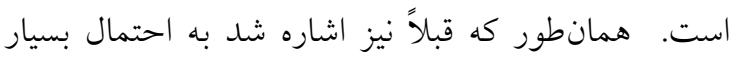
زياد اين كونه متعلق به بخش chameamygdalus است.

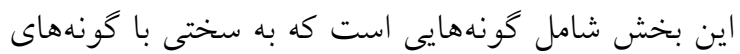
زراعى تلاقى مىيابند و در قسمتهاى شوروى سابق بحس بهى

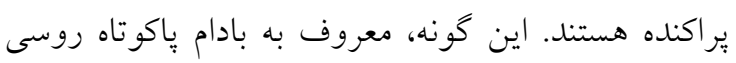

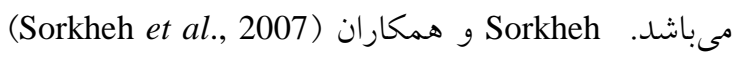

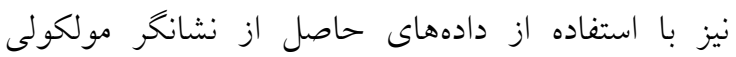
AFLP توانستندA A. tenella را از ساير گونهها جدا كنند. هazbek and Oh, ) Yazbek and Oh همانطور كه 2013) گزارش كردند مى توان بيان داشت كه P. tenella به Amygdalus
كونه Socias i Company g. glauca در طبقهبند ندارد، ولى با استفاده از دندروگرام حاصل از دادههاى

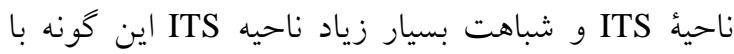
Pاير گونهاى موجود در گروه Amygdalus مى مانوان

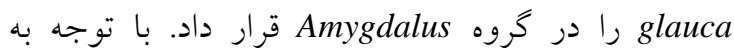

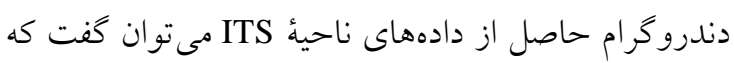
تنها قادر به جدا كردن گروههاى Prunus از يكديخر مىباشد و در جداسازى بخشها تو انايى لازم را ندارد. فيلوزنى بادام با استفاده از دادههاى ناحية trnL زن كلرويلاستى: دندروكرام مربوط به دادههاى ناحية زن كلرويلاستى (شكل r) كه با استفاده از روش مرئ آناليز Mega بدست آمد، به دو گروه اصلى تقسيم مىشود.

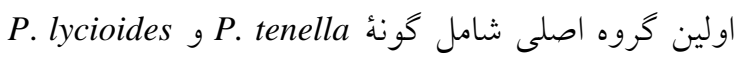
مىباشد. P. tenella هم:جنان كه در دندروكرام حاصل از 


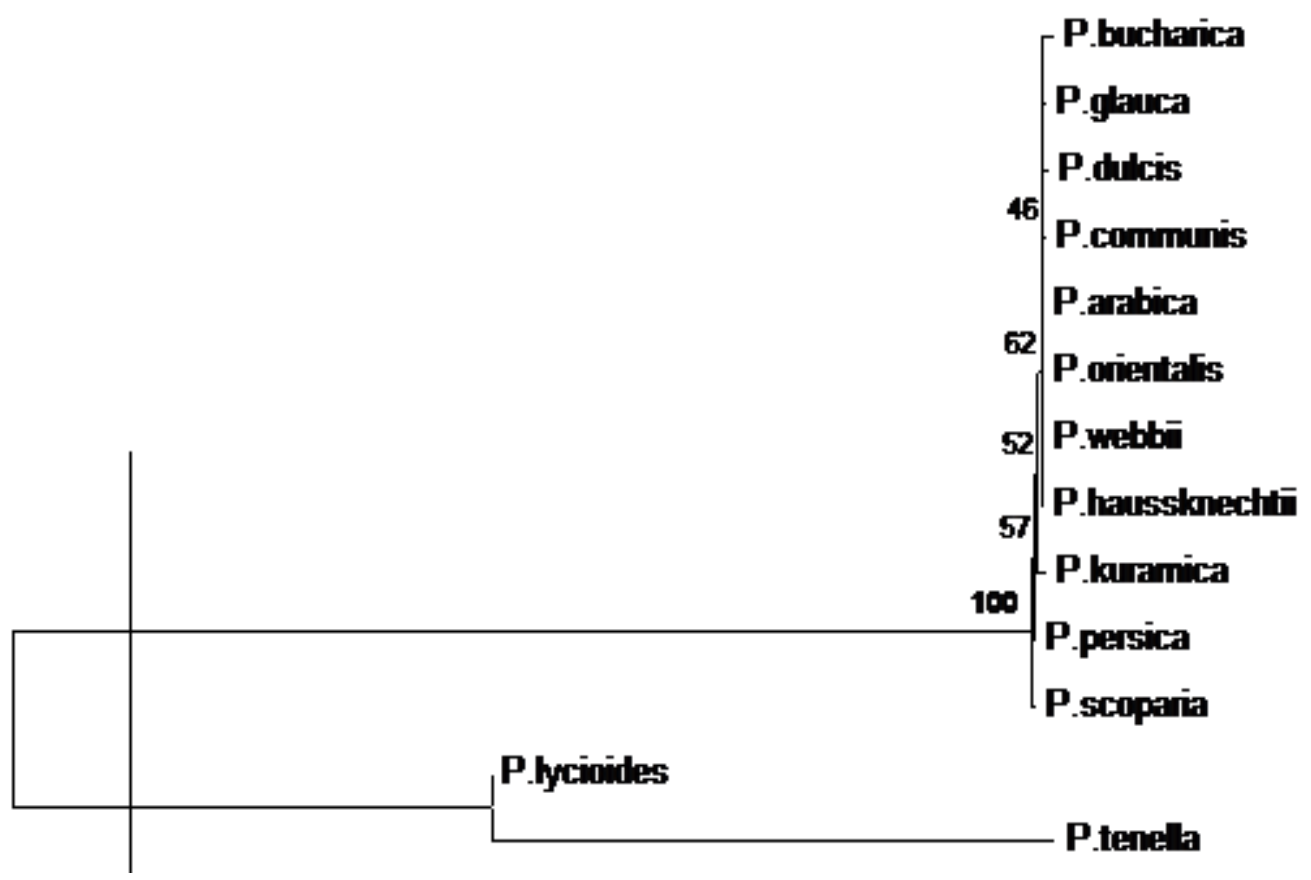

شكل س- كروهبندى گونههاى وحشى بادام با استفاده از دادههاى ناحية trnL زن كلرويلاستى

Figure 3. Classification of wild almond species using trnL chloroplastic genes data region

روابط بين گروههاى جنس Prunus گزارش شده است. آنها نتوانستند رابطة درستى را بين كونههاى مربوط به زيرجنس trnL-F Amygdalus با ارائه بدهند و عنوان نمودند كه Amygdalus بار افيلتيك مىباشد. Gilani

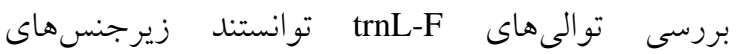
9 Padus ،Prunus ‘Cerasus Amygdalus P. را از يكديخر جدا كنند و همجزنين Laurocerasus persica دهند. در نتيجه مىتوان بيان داشت، trnL-F فقط قادر به جدا كردن زيرجنس هاى Prunus مىباشد ( Bortiri et trnL al., 2006 (al. همانطور كه در شكل ب ديده مىشود نيز در اين مطالعه تنها توانست chameamygdalus را از ساير بخشها جدا كند و در جدا كردن بخشهاى Euamygdalus مطلب بيانگر شباهت زياد توالى trnL زن كلرويالاستى اين دو بخش مىباشد و هم:جنين توالى trnL بخش
قبلاً گزارش شده اسن كه بخش chameamygdalus كونههايى را در بر مى گيرد كه از نظر زنتيكى نسبت به كونهاى ساير بخشها تنوع بيشترى ييدا كردهاند MST Kester and Assay, 1991) Bouhadida et al., ) و همط Bماران Bouhadida 2007) بيانكر روابط بسيار نزديكى در بين هايلوتيٍِهاى (بuamygdalus Amygdalus نمودند كه احتمالاً DNA كلرويّاستى P. tenella نسبت به ساير گونهاى Amygdalus بيشتر تحت عوامل ايجاد تنوع قرار كرفته است. با توجه به اندازه متفاوت ناحيه

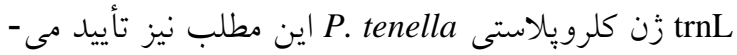
شود (اندازهُ توالى همأ كونهها اندازه توالى 09.bp P. tenella است). ميزان فاصلة زنتيكى ناحية زن trnL كلروبِاستى بسيار كم است كه اين موضوع محدوديتى در شناسايى روابط ميان گونههاى تحت بررسى مىباشد. اين محدوديت قبلاً توسط Bortiri و همكاران (Bortiri et al., 2001) نيز در شناسايى تعيين 
بر اساس كزارشات قبلى ( Bortiri et al., 2006; Lee and و مطالعة حاضر مىتوان (Wen, 2001; Wen et al., 2008 كزارش نمود كه ناحية ndhF و trnL-F و trnL حتى در حد گونه هم حفاظت شده است. بنابر اين براى جداسازى كونهاى مربوط به زيرجنس Amygdalus بايد نواحى ديخرى از DNA كلرويهاستى مورد استفاده قرار كيرد. هرجيند از نواحى زن كلرويٍاستى MST براى بيدا كردن جد مادرى كونههاى Prunus استفاده شد Bouhadida) Potter et al., 2000) و همكاران (et al., 2007 روابط فيلوزنتيك Rosaceae را با استفاده از آناليز يارسيمونى دادههاى حاصل از توالى يابى دو ناحيه از زنوم

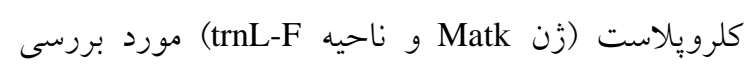
قرار دادند و به نتايجـى مشابه با Bortiri و همكاران (Bortiri et al., 2001)

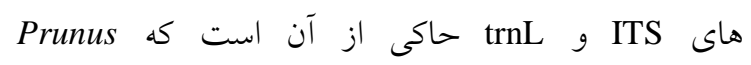
مونوفيلتيك مىباشد. اين نتايج با ساير مطالعات فيلوزنتيك Bortiri et al., 2001; Vadafar et al., ) مطابقت دارد

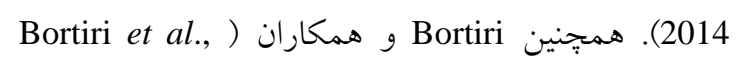
2001) بيان داشتند كه Prunus را نمىتوان به دو يا جند جنس تقسيم كرد و دليل آن را وجود شاخههاى كوتاه در Prunus مقايسه با Outgroup مى مانست. در دندرو مرامهاى حاصل، براى هر جفت از گونهها امكان تعيين فواصل زنتيكى فراهم نشد و ميانخين فاصلهُ زنتيكى در بين كونهها كمترين فاصلة زنتيكى را در داخل جنس نشان داد. بنابراين، طبق آناليز دادهها و يافتههاى مطالعه حاضر مىتوان بيان داشت Prunus بصورت تك جنس' مىباشد كه اين مطلب با نتايج ديخران (Bortiri et al., 2001) مطابقت دارد. اين مطالعه مىتواند اطلاعات مولكولى مفيدى براى حل مسأله فيلوزنتيك گونههاى وحشى بادام ايران ارائه دهد و به طيف وسيعترى از گونههاى بادام و توالىهاى مختلف مولكولى از زنهاى مختلف و با درجه بالايى از تنوع نياز است.

1- Single genus
نسبت به اين دو بخش از تنوع chameamygdalus بالاترى برخوردار است. با توجه به شباهت بسيار زياد ناحية trnL در كونه triى وحشى بادام مورد مطالعه در اين Prunus بزوهش، مىتوان كزارش كرد كه جد مادرى يكى مىباشد و نشانگر trnL براى جداسازى كونههاى وحشى بادام مناسب نيست.

ITS1-5.8s فيلوزنى بادام با استفاده از دادههاى ناحية rDNA-ITS2 مشترى trnL و ITS با استفاده از نرمافزار PAUP گونهها را به سه كروه اصلى تقسيم نمود. Bortiri و همكاران عنوان نمودند كه نتايج حاصل از (Bortiri et al., 2006) دادههاى trnL همراه باه هم به نتايج حاصل از آناليز توالىهاى ITS شباهت بيشترى دارد و علت اين موضـوع را در تعداد بيشتر (دو برابر بيشتر) مكانهاى مؤثر (بيانخر اختلاف) مىدانند و بيان مى كنند كه تركيب دادههاى ITS و trnL باعث كاهش سطح هومويلاستى مىشود. اين موضوع نيز با نتايج حاصل از تركيب دادههاى ITS و trnL در اين تحقيق، مطابقت دارد. ITS Bortiri و به منظور ايجاد روابط فيلوزنى جنس PrnL-Fus

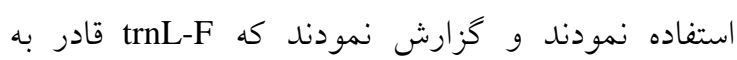
شناسايى روابط فيلوزنى Rosaceae نمىباشند و آناليز تركيب trnL-F و آنها با آنجه ITS Lee ) Lee and Wen trnL-F كزارش نمودند، مبنى بر اينكه (and Wen, 2001 نمىتواند روابط فيلوزنى Rosaceae را مشخص كند، همخوانى دارد. Wen و همكاران (Wen et al., 2008) به لهوتئ بررسى ناحية ndhF زن كلرويلاستى به منظور تعيين روابط فيلوزنتيك در جنس Prunus يرداختند و بيان نمودند كه درخت فيلوزنى مربوط به ناحية ndhF با آنجه لمونه قبلاً در اين باره گزارش شده بودد، كاملاً توافق داشت. هرجِند نتايج حاصل از توالى ITS آنها با آنجه قبلاً كزارش شده بود ) Bortiri et al., 2006; Lee and Wen, 2001)، تناقض داشت. 


\section{References}

Baldwin, B.G. (1993). Molecular phylogenetic of Calycadenia (Compositae) based on ITS sequences of nuclear ribosomal DNA: chromosomal and morphological evolution reexamined. American Journal of Botany, 80: 222-238.

Baldwin, B.G., Sanderson, G.M.J., Porter, J.M., Wojciehowski, M.E., Campbell, C.S. and Donoghue, M.J. (1995). The ITS region of nuclear ribosomal DNA: a valuable source of evidence on angiosperm phylogeny. Annals of the Missouri Botanical Garden, 82: 247-277.

Bortiri, E., Oh, S.H., Jiang, J., Baggett, S., Granger, A., Weeks, C., Buckingham, M., Potter, D. and Parfitt, D.E. (2001). Phylogeny and systematics of Prunus (Rosaceae) as determined by sequence analysis of ITS and the chloroplast trnL-trnF spacer DNA. Systematic Botany, 26: 797807.

Bortiri, E., Vanden, H. and Potter, D. (2006). Phylogeny and systematics of Prunus (Rosaceae) as determined by sequence analysis of ITS and the chloroplast trnL-trnF spacer DNA. Systematic Botany, 26: 797-807.

Bouhadida, M., Martin, J.P., Eremin, G., Pinochet, J., Moreno, M.A. and Gogorcena, Y. (2007). Chloroplast DNA diversity in Prunus and its implication on genetic relationships. Journal of the American Society for Horticultural Science, 132(5): 670-679.

Browicz, K. (1969). Amygdalus. In: Rechinger, K.H. (ed.), Flora Iranica: Rosaceae, Akademische Druck und Verlagsanstalt, Graz. 166-187.

Gilani, S.A., Qureshi, R.A., Khan, A.M. and Potter, D. (2010). A molecular phylogeny of selected species of genus Prunus L. (Rosaceae) from Pakistan using the internal transcribed spacer (ITS) spacer DNA. African Journal of Biotechnology, 9(31): 4867-4872.

Kester, D.E. and Assay, R. (1975). Almond", In: Advance in fruit breeding (ed. Janick J. and J. N. moore), Purdu Univ. Press West Lafayette, Indiana, 387-419.

Kester, D.E., Gradziel, T.M. and Grassely, C. (1991). Almonds (Prunus), In: M. Moore and J.R. Ballington. Jr. (eds). Genetic resources of temperate fruit and nut crops. International Journal of Horticultural Science and Technology, 701-758.

Khanuja, S.P.S., Shasany, A.K., Darokar, M.P. and Kumar, S. (1999). Rapid Isolation of DNA from Dry and Fresh Samples of Plant Producing Large Amounts of Secondary Metabolites and Essential oils. Kluwer Academic Publishers, The Netherlands.

Khatamsaz, M. (1992). Flora of Iran. No. 6: Rosaceae, Research Institute of Forest and rangelands.

Lee, S. and Wen, J. (2001). A phylogenetic analysis of Prunus and the Amygdaloideae (Rosaceae) using ITS sequences of nuclear ribosomal DNA. American Journal of Botany, 88: 150-160.

Martınez-Gomez, P., Arulsekar S., Potter D. and Gradziel, T.M. (2003). An extended interspecific gene pool available to peach and almond breeding as characterized using simple sequence repeat (SSR) markers. Euphytica, 131: 313-322.

Potter, D., Gao, E., Oh, S.H. and Baggett, S. (1999). Molecular phylogenetic studies in Rosaceae. P. 39. in International Botanical Congress-Abstracts.

Potter, D., Lubyand, J.J. and Harrison, R.E. (2000). Phylogenetic relationships among species of ragaria (Rosaceae) inferred from non-coding nuclear and chloroplast DNA sequences. Systematic Botany, 25: 337-348.

Rahemi, A., Fatahi, R., Ebadi, A., Taghavi, T., Hassani, D., Gradziel, T., Folta, K. and Chaparro, J. (2012). Genetic diversity of some wild almonds and related Prunus species revealed by SSR and EST-SSR molecular markers. Plant Systematic and Evolution, 298: 173-192.

Socias i Company, R. (1998). La taxonomie de l'amandier. Cahiers Options Mediterr, 33: 91-93.

Sorkheh, K, Shiran, B., Gradziel, T.M., Epperson, B.K., Martinez-Gomez, P. and Asadi, E. (2007). Amplified fragment length polymorphism as a tool for molecular characterization of almond germplasm: genetic diversity among cultivated genotypes and related wild species of almond, and its relationships with agronomic traits. Euphytica, 156: 327-344.

Taberlet, P., Gielly, L., Pautou, G. and Bouvet, J. (1991). Universal primers for amplification of three non-coding regions of chloroplast DNA. Plant Molecular Biology, 17(5): 1105-1109.

Vadafar, M., Attar, F. and Maroofi, H. (2010). Trichome micromorphology in drupe of Amygdalus L. (Rosaceae) from Iran. Acta Botanica Croatica, 69(1): 93-105. 


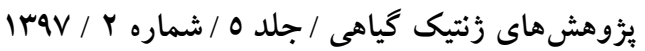

Vadafar, M., Kazempour, S.H. and Attar, F. (2014). Molecular phylogeny of the genus Amygdalus (Rosaceae) based on nrDNA ITS and cpDNA trnS-trnG sequences. Turkish Journal of Botany, 38: 439-452.

Wen, J., Berggren, S.T., Lee, C.H., Ickert-Bond, S., Yi, T.S., Yoo, K.O., Xie, J., Shaw, D. and Potter, D. (2008). Phylogenetic inferences in Prunus (Rosaceae) using chloroplast ndhF and nuclear ribosomal ITS sequences. Journal of Systematics and Evolution, 46(3): 322-332.

Yazbek, M. And Oh S.H. (2013). Peaches and almonds: phylogeny of Prunus subg. Amygdalus Rosaceae) based on DNA sequence and morphology. Plant Systematics and Evolution, 299: 14031418.

Murray, M.G. and Thompson, W.F. (1980). Rapid isolation of high molecular weight plant DNA. Nucleic Acids Research, 8(19): 4321-4325. 


\title{
Study on Phylogenetic Relationship among some of Iranian Wild Almond Species using Sequences of ITS1-5.8S rDNA-ITS2 Region and Chloroplastic trnL
}

\author{
Seyedeh Zahra Hosseini ${ }^{1}$, Behroz Shiran ${ }^{2}$ and Mohammad Ali Ebrahimi,"* \\ 1- Former M.Sc. Student, Department of Agricultural Biotechnology, Payame Noor \\ University, Tehran, Iran \\ 2- Professor, Department of Plant Breeding and Biotechnology, Faculty of Agriculture, \\ Shahrekord University, Shahrekord, Iran \\ 3- Associate Professor, Department of Agricultural Biotechnology, Payame Noor University, \\ Tehran, Iran
}

(Received: June 20, 2018 - Accepted: October 20, 2018)

\begin{abstract}
Phylogenetic relations among 12 wild species of almonds, one cultivated almond and one species of peach were investigated by using of ITS1-5.8S rDNA-ITS2 sequences and trnL region of chloroplast DNA. To do this, maximum-parsimony and neighbor joining analysis adopted. Results of ITS data showed that studied species of Prunus only divided in two groups but incapable to separate different sections. $P$. tenella showed more diverse genetic distance in compare to other studied species and it seems that this species does not belong to Amygdalus. Also, by using the ITS data it can be reported that Prunus is monophyletic. In this research, the genetic distances for each pair of species were determined and the average genetic distance between species shows only the lowest genetic distance within the genus. Therefore, Prunus is a single genus. Regarding its high similarity of trnL region in wild almond species, it can be reported that maternal ancestor of Prunus is the same and trnL is not optimum marker to separate species of almond.
\end{abstract}

Keywords: Phylogeny, ITS1-5.8S rDNA-ITS2, Prunus species, trnL chloroplast

\footnotetext{
${ }^{*}$ Corresponding Author, E-mail: ma_ebrahimi@ pnu.ac.ir
} 